\title{
IgM and IgG antibody response to SARS-CoV-2 Infection and Viral RNA Persistence in hospitalized chronic kidney disease patients under Hemodialysis (HD)
}

Sir,

Patients receiving kidney replacement therapy are a vulnerable population as those receiving HD are usually older with significant co-morbidity and also have impaired immune responses. ${ }^{1}$ Serological tests are used to confirm infection with SARS-CoV-2, but the extent to which antibody positivity translates to actual immunity is still under consideration. ${ }^{2}$

14 Covid-19 positive HD patients on a nasopharyngeal swab were treated under the care of our facility during the period 8 April 2020-17 June 2020. Nine patients displayed signs and symptoms of Covid-19. 5 patients died (at days 1, 7, 12, 27 and 38) and 9 patients recovered clinically and were discharged from the hospital. In those 9, IgM antibodies were detected after 15 days (range: 3-26) from confirmation of Covid-19 infection and $\operatorname{IgG}$ antibodies were detected after 23 days (range:7-38) from confirmation of Covid-19 infection. $2 / 5$ deceased patients never developed $\operatorname{IgM}$ and $\operatorname{IgG}$ antibodies. 3/5 deceased patients developed IgM and IgG antibodies 17 and 25 days respectively from confirmation of Covid-19 infection. In survivors, first negative PCR was 43 days after admission to hospital (range: 35-56). IgM, IgG antibodies and PCR never detected in dialysate waste products after the end of HD sessions.

In conclusion, asymptomatic and symptomatic $\mathrm{HD}$ patients are able to mount an antibody response ( $\operatorname{IgM}$ and $\mathrm{IgG}$ ) against Covid-19. Timing seems to be varied with a delay of approximately a week to that of the nondialysis population. However, $\operatorname{IgG}$ antibodies appeared 3 weeks before the actual clearance of the virus. Viral shedding persisted for an average of 6 weeks period. Eventhough infectiousness period has not been clarified, ${ }^{3}$ due to late antibody response,
Access this article online

Website:

http://nepjol.info/index.php/AJMS DOI: 10.3126/ajms.v12i7.36498 E-ISSN: 2091-0576 P-ISSN: 2467-9100

Copyright (c) 2021 Asian Journal of Medical Sciences

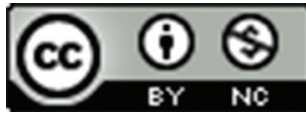

This work is licensed under a Creative Commons Attribution-NonCommercial 4.0 International License.

we suggest on the basis on our implementation, negative PCR testing of at least two sequential samples before lifting quarantine in $\mathrm{HD}$ patients.

Keywords: Covid-19; IgM and IgG Antibody Response; Chronic Kidney Disease

loannis Griveas

Consultant Nephrologist, Medical Director Nephrology Department Army Share Fund Hospital of Athens, Greece 362 Kifisias Ave, 15233, Chalandri, Athens, Greece

Address for Correspondence: Dr. loannis Griveas, 362 Kifisias Ave, 15233, Chalandri, Athens, Greece. Mobile: 00306932379323.

E-mail: giannisgriv@hotmail.com

\section{REFERENCES}

1. Kato S, Chmielewski M, Honda H, Pecoits-Filho R, Matsuo S, Yuzawa $Y$, et al. Aspects of immune dysfunction in end-stage 
renal disease. Clin J Am Soc Nephrol. 2008;3(5):1526-1533. https://doi.org/10.2215/CJN.00950208

2. Melgaço JG, Azamor T and Ano Bom APD. Protective immunity after COVID-19 has been questioned: What can we do without SARS-CoV-2-IgG detection? Cell Immunol 2020; 353:104114. https://doi.org/10.1016/j.cellimm.2020.104114

3. Wölfel R, Corman VM, Guggemos W, Seilmaier M, Zange S, Müller MA, et al. Virological assessment of hospitalized patients with COVID-2019. Nature. 2020; 581(7809):465-469.

https://doi.org/10.1038/s41586-020-2196-x

Authors Contribution:

IG - Writing-planning.

ORCID ID:

Dr. Griveas loannis- (i) https://orcid.org/0000-0003-3588-8532

Source of Support: Nil, Conflict of Interest: None declared. 